INDEPENDENT JOURNAL OF MANAGEMENT \& PRODUCTION (IJM\&P)

http://www.ijmp.jor.br

v. $11, n$. 7, November - December 2020

ISSN: 2236-269X

DOI: 10.14807/ijmp.v11i7.1230

\title{
ETHNOGRAPHY IN ORGANIZATIONAL STUDIES: A REFLECTION ON THE IMPORTANCE OF PERFORMANCE EVALUATION IN \\ TOURISM
}

\author{
Rogeane Morais Ribeiro \\ Faculdade Luciano Feijão, UNIVALI, Brazil \\ E-mail: rogeanemorais@yahoo.com.br \\ Ruan Carlos dos Santos \\ Centro Universitário UniAvan, UNIVALI, Brazil \\ E-mail:ruan_santos1984@hotmail.com \\ Maria do Socorro Silva Mesquita \\ Universidade do Ceará-UFC, Faculdade Ari de Sá, Brazil \\ E-mail: socorromesquita@yahoo.com.br \\ Cristiane Saboia Barros \\ Instituto Federal doCeará (IFCE), UNIVATES, Brazil \\ E-mail: cristianesaboia@hotmail.com
}

Submission: $12 / 29 / 2019$

Revision: $2 / 2 / 2020$

Accept: 2/12/2020

\section{ABSTRACT}

The present research aims to understand the feasibility of developing a multidimensional model of performance evaluation for organizational control in companies through ethnographic research. Thus, a bibliographic analysis of the studies presented in the four main events of the Brazilian organizational studies - the Colloquium of Epistemology and Sociology of Administration Science, CBEO, EnANPAD and EnEO - and in the research bases SPELL and EBSCO. The measurement of performance in a company has become a relevant subject for both academic research and practical application, because organizational control of organizational control serves to evaluate and improve the various organizational processes to establish goals and achieve performance standards that become competitive in the market. Given this context, we can see that there is a vast possibility of development in this field, through an ethnographic research, through an investigation capable of showing practices, people, groups, cultures and networks of social relations that participate differently from the tourist market, since the environment in which companies are increasingly turbulent and unstable, and decision makers are constantly seeking methods to 
DOI: 10.14807/ijmp.v11i7.1230

achieve improvements in organizational performance. In this sense, it is concluded that this research offers theoretical information that can help in future studies that seek to develop a multidimensional model of indicators, besides being a source of data on the diversity of organizational indicators.

Keywords: Multidimensional; Hospitality; Performance

\section{INTRODUCTION}

The studies on performance evaluation have been presented relevant and companies of any segment constantly seek to adapt to the current paths that the market presents with the intense changes and high competitiveness, demanding a higher level of efficiency and effectiveness. In this context, the emergence in recent decades of new trends has been observed, and the tourism sector has experienced continuous expansion and diversification, becoming one of the fastest growing global economic sectors, promoting technological innovation, and providing new markets and employment opportunities.

The investigations by Alves (2013), UNWTO (2012), and UNWTO (2013) show that the activities measured by the total international landings demonstrate the vigor of this growth. Considering that the year 2016 was decisive for tourism, a year of growth above the average, even with many challenges reached 1,200 million and according to estimates the number of tourists coming from other countries should reach 1,600 million of passengers until the year 2020, and that growth has accompanied the dignity that the tourism segment must firmly commit (UNWTO, 2012; UNWTO, 2013).

In this vision, it is perceived that the hotel industry is immersed in a highly competitive environment and needs accurate and reliable information for the proper management of activities. Hotel companies, like any other firm and any segment, can apply indicators in order to produce information for the decision-making process of their managers, seeking to develop the performance of the business. However, little is known about tourism management, mainly in hotel companies, which aligns the need to expand knowledge about the management context and performance of companies in that sector (PAVLATOS; PAGGIOS, 2009).

In the last three decades, a growing academic interest has been detected aimed at measuring performance in the hotel network. Although it is a subject of great acceptance in the field of research, it is perceived that the concept of tourism performance is not totally 
DOI: 10.14807/ijmp.v11i7.1230

structured, the performance of organizations, regardless of the segment, remains one of the most popular concepts in organizational research (MILLER; WASHBURN; GLICK, 2013).

In the same line of thinking we have Sainaghi (2010); Sainaghi, Phillips and Corti, (2013); Cheng and Coyte (2014); Phillips and Moutinho (2014), and Sainaghi et al. (2017) that relate the existence of a positive relationship in the integration of performance indicators and global business strategy, including a wide range of measures, but that must necessarily include financial and non-financial metrics, as well as in the vision Sainaghi et to the (2013) in tourism, the construction of performance measures must be multidimensional. Affirming that performance measures continue to be one of the most critical activities for researchers interested in tourism management. From the presented presentation, it is intended to understand the viability of the development of a multidimensional performance evaluation model for organizational control in companies of the hotel segment through ethnographic research.

Within the framework of the introductory contextualization and the objective, the vision of Jaime Jr. (2003) is presented, where he points out that ethnography can lead to deepening knowledge about organizational reality, but Cavedón (2014) emphasizes the relevance of sociological bases that sustain the application of the ethnographic perspective in organizational studies. In the field of tourism, ethnographic research would be appropriate, since the researcher participates in the daily life of individuals over an extended period, observing and witnessing accessible information to deeply visualize the topics that were chosen to study (HAMMERSLEY; ATKINSON, 1994).

With focus on the objective of the study, after this contextualization, the ethnographic method is presented in the study of tourism, organizational performance and ethnographic perspectives and final considerations.

\section{LITERATURE REVIEW}

\subsection{Reflective attributes for the ethnographic study}

Ethnography is a form of social research that has the following main characteristics: i) Strong emphasis on the exploration of the nature of a given social phenomenon (instead of testing hypotheses about that phenomenon); ii) use, mainly, of unstructured data; iii) the detailed investigation of a single case or a small number of cases; iv) data collection with individuals and / or groups; and v) Analysis of data, usually concomitant with its collection, which implies interpretation of the meaning of human actions, generating descriptions and explanations as the main final product, although it may still have statistical analyzes acting as 
DOI: 10.14807/ijmp.v11i7.1230

a coadjutant (ATKINSON; HAMMERSLEY, 1994; FETTERMAN, 2010). For Brewer (2004) the methods to be used in an ethnographic study must allow the researcher access to the activities of the individuals of the group, and the techniques include: interviews, discourse analysis, documentary analysis and participant observation

Ethnography seeks to describe in detail, by themes or perspectives, a culture or a social group that shares the same culture, where the researcher examines people in their natural habitat, using methods to capture their social meanings and routine activities, seeking to detect patterns of behavior, customs, and general ways of life, interpreting that group in relation to the meanings of social interactions and generalizations about social life (BREWER, 2004).

Ethnography is based on the assumption that each social group is different and, in order to study such differences, the researcher must engage with the group in their own space (JUPP, 2006). Therefore, ethnographic studies are conducted to satisfy three simultaneous needs related to the study of human activities: (i) the need for an empirical approach, since the phenomenon to be studied should not be inferred, requiring empirical responsibility; (ii) the researcher's need to remain open to elements that cannot be coded during the study; and (iii) a union by the phenomenon observed in the field (BASZANGER; DODIER, 1997).

In the case of ethnography, ethnography is strongly associated with its own philosophical framework, called naturalism, which is concerned with the study of social life in the place where it actually occurs, since it happens independently of experimental manipulation. Vergara (2008), an ethnographic study allows the researcher to understand in a broader way how individuals act in a certain environment, which can be an organization, a society, or a group that shares cultures and subcultures. This type of research also makes it possible to identify the characteristics, values and symbolisms of these groups of individuals studied.

In the case of ethnographic research they have mainly contributed to the refinement of qualitative research in tourism, to the extent that they enable a better understanding of the dynamic, procedural and systemic nature of the activity, helping to understand models that differ from the Aegean of the tourist market.

Such research covers Western and non-Western contexts, urban and rural, traditional and modern, producing a diversity of views on places and tourist practices. (...) the anthropologists also carried out participant research among Chinese, Japanese, Korean, 
DOI: 10.14807/ijmp.v11i7.1230

Laotian, Indonesian, Indian, Indian, Brazilian, Mexican and Middle Eastern tourists, both in national and international trips "(GRABURN, 2009, p. 14).

Ethnography can be used as a methodological option that goes against dehumanized, superficial and sterile research models, transforming itself into a tool of cultural relativization, insofar as it studies the facts in its own context, starting from the point of reference (in the case of women). In addition, it can also contribute to the understanding of the material and symbolic elements that involve the forms of manipulation and resistance; as well as contrasts, conflicts and asymmetries in the interior of the tourist activity. The method

"[...] it deepens the relativization of cultural points of view, of the reciprocal relationships inherent to each group and of the strategic differences of decision of the actors, as well as making it possible to consider the non-rational character of a large part of the behaviors in the societies and of the groups and institutions involved” (SANTANA, 2009, p. 22-23).

In this sense, the field work of ethnography in the evolution of tourism makes it possible to see people, experiences, social networks and exchange systems, which go unnoticed from far away and outside of other methodological models, also becoming a means of give voice to the native populations that make viable and lead the tourist development in their territories (LEAL, 2010).

In studies linked to tourist travel, for example, the ethnographic perspective can give visibility to spaces of transitory circulation that temporarily accommodate those in transit, transforming interiors of means of transport, gas stations, accommodation facilities, roads and airports in important research spaces, which is inserted in what Augé (2007) calls cultural analysis, where such research can privilege the earlier, the during and the later of the trip and, according to the objectives of the research, work with different instruments of data collection.

\subsection{The Ethnographic Method in the Tourism Study}

Leal (2010), Pinto and Pereiro (2010) report that the first studies relating anthropology and tourism began in 1960, where they verified the impacts caused in the relationship between the former colonies of the Caribbean, Africa and Asia under the influence of the centers water generators tourist flows, based on this, ethnographic research contributes to the systematization of qualitative research in tourism, broadening the understanding of the natural and of the process, reviving diverse views on local and tourist practices.

In this context, research on financial, operational and sociocultural processes appear in various areas in interaction with the tourism segment, such as Geography, Anthropology, Sociology, Psychology, but it can be considered that in the Administration these investigations 
DOI: 10.14807/ijmp.v11i7.1230

find and are quite present, because it is considered that this area contributes in several aspects in congruence with different issues. Tourism planning is historically demarcated by theories and practices of the administration area involving future scenarios based on world market trends (BARRETTO, 2003).

Globalization appears as a specific term of culture, which refers to referring to cultural transitions worldwide. When describing the socio-cultural changes of tourism in the receiving localities, the process of cultural globalization cannot be ignored, that is, placing all the blame for socio-cultural transformations on tourism without reflecting on this situation in the globalized world (ORTIZ, 2000, p. 78).

To understand the organizational phenomena it is necessary to overcome the knowledge to understand the horizon of the ways in which social actions are developed, where in the vision of Magallanes and Santos (2016) they can be considered as the communication between the mediator and the formator of lived experiences. socially. In the social sciences, phenomenology, previously synonymous with anything other than positivism, achieved greater conceptual and methodological rigor (REMENYI et al., 1998; EMBREE, 2001).

The importance of ethnography lies in its complexity, which makes it possible to know and update theories insofar as they are observed in practice, and this possibility is marked by the immersion of the research field, since the researcher lives the sociocultural routine and can analyze in detail the practical relationships and social interactions that occur in the daily research (GEERTZ, 1978).

In this way, we can consider tourism as a complex social phenomenon with the capacity to produce profound social changes in diverse organizations and societies, being difficult to understand tourism and social research distant from modern societies, as the complexity of the tourist phenomenon makes it based in interrelations, and thus, it can be observed to obtain the necessary knowledge about tourism (TEDLOCK, 2000).

Ethnographic research involves the description of the events and interactions that occur in the life of a group, being able to focus on different types of civilizations, communities and organizations (GODOY, 1995).

Tourism studies currently encompasses a multiplicity of thematic areas, being little evolved and considered a broad field for research. Ricthie and Ritchie (2002) consider that tourism research is used inefficiently and rarely exploited to its full potential. Ethnography is being discovered as a theoretical approach that broadens the understanding of the dynamics of 
DOI: 10.14807/ijmp.v11i7.1230

activity in tourism studies (PIOLA; KUSHANO, 2018). The ethnographic description is shown as a comprehensive theoretical approach to tourism, allowing the delineation of a comprehensive methodological model of tourism systems, overcoming the reductionist visions that limit its multiple dimensions and consequences (PINTO; PEREIRO, 2010).

\subsection{Organizational performance and ethnographic perspectives}

In the approach of ethnography to organizational studies, it is important to point out that in the vision of Godoy (1995) ethnography goes beyond the technique where construction takes place in loco, since it establishes relationships for a better understanding of the complexity of social phenomena. The issue of organizational performance has been presented with great relevance in social science research and even that empirical studies have not succeeded in advancing in a universal theory or concept authors Cameron and Whetten (1983), Lewin and Minton (1986) affirm that , the issue of organizational effectiveness has served as a unifying theme for more than a century.

In this sense, the vision of Geertz (1978), affirming the importance of ethnography is based on its complexity, which allows updating the theories to the extent that they are observed in practice, being the case of performance evaluation (organizational studies ), one of the topics (in the case of women). But the authors emphasize that this relationship is not exhaustive, but seeks to encourage researchers in organizational fields and acquire an ethnographic position in their studies. The conception of the thematic field of study is considered as singular moments, therefore the routine refers to the social totality, enabling these experiences to build the ethnographic context, where the researcher's and researched's vision is constantly questioned (ANDION; SERVA, 2006, p. 56).

Ethnography is based on the immersion of the research field, where the researcher participates, lives and can normally be affected by daily customs and local socio-cultural functionality, making it possible to obtain detailed and organized data on social practices and interactions that enrich the study. In that sense, the scientific studies related to the organizational performance issue do not see presenting difference in the several researches pointed out. Kaplan and Norton (1992) defend as a system adopted by the organization that strongly affects the behavior of executives and officials and that managers want a balanced presentation of both financial and operational indicators. 
DOI: 10.14807/ijmp.v11i7.1230

Following the perspectives of ethnographic research we have a conceptualization for performance evaluation, which in the vision of Sainaghi and Baggio (2016) the organizational performance is seen as a network, a complex system.

In addition, ethnography allows the researcher investigate a large number of people, even more than when using ethnography. Therefore, it can be said that ethnography helps society to better understand society and the evolutionary behavior of tourism. On the other hand, compared to ethnography, tourism research is restricted to online communities, while ethnography can focus on the whole of human society (KOZINETS, 2012). While, ethnography comprises research on all forms of human communication, including body language and tone of voice (BARTL et al., 2016), tourism finds its advancement in information technology in real time in supported online content, which is mainly textual communication, including some features elements.

This concept goes to meet the thinking of Andion and Serva (2006), when they argue that in organizational studies, networks have been the object of many studies, taking into account that in several cases organizational networks are attributed a sense of innovation in the sphere of civil society, of the market or of the State, because it provides necessary information for decision making, as well as the possibility of a competitive advantage in continuous operations.

\section{METHODOLOGICAL ASPECTS}

In order to meet the proposed objective, which consists in evaluating the way in which the ethnographic method has been used in Brazilian organizational studies, this bibliographical study was developed.

According to Gil (2008, p. 97), "the bibliographic research is developed based on material already prepared, consisting mainly of books and scientific works". In the present work the results of the evaluation of the results obtained in the analysis of the results obtained in the study were analyzed: Yen-Tsang, Dultra-De-Lima and Pretto (2012) and Magalhães and Dos-Santos (2013), then to add in the studies a collection was made in the SPELL and EBSCO research bases. The election of these events is due to their importance and representation in the national academic scenario, as well as to believe in the potential of these for the development of the field of organizational studies.

With regard to data collection, the annals of the events were used, searching the articles for the following keywords: "ethnography", "organizational studies" and "tourism". In the case 
ISSN: 2236-269X

DOI: 10.14807/ijmp.v11i7.1230

of EnanPAD, 12 editions were analyzed (2006 to 2018), of the EnEO 7 editions were analyzed (2006, 2008, 2010, 2014, 2016, 2018), of the Cbeo, 6 editions were analyzed (2013 to 2018), from the Colloquium of Epistemology and Sociology of the Science of Administration, editions were analyzed (2011 to 2018), in the SPELL database (Scientific Periodicals Electronic Library) and EBSCO (the articles the criterion, "most cited" and "relevance" between 2006 and 2018), focusing only on articles published in national and international journals.

As results of the search in the annals of each event and research base, the following amounts of studies were found. Before the studies, we will have the percentage of article by the amount of articles published in events and in the bases of Investigations.

Table 1: Articles found in the annals of events and in the bases of research

\begin{tabular}{|c|c|c|c|}
\hline Event / Research Base & No. Editions / Year & Quantity & Percentage of Article Per Year / Event \\
\hline Cóloquio de Epistemologia & 8 & 15 & $1,88 \%$ \\
\hline EnEO & 7 & 28 & $4,00 \%$ \\
\hline CBEO & 6 & 38 & $6,33 \%$ \\
\hline EnANPAD & 12 & 95 & $7,92 \%$ \\
\hline SPELL & 12 & 549 & $45,75 \%$ \\
\hline EBSCO & 12 & 1025 & $85,42 \%$ \\
\hline
\end{tabular}

Source: Adapted from Magallanes and Santos (2016), Costa and Fonseca (2018)

After the articles were collected by events and data analysis, the articles listed in the previous table were selected and analyzed. Thus, first an analysis of some aspects was carried out, such as: authorship, origin, temporal space, in which the articles were developed. After a qualitative analysis was developed based on the categories of analysis delimited from the review of the main authors, which sought to approximate the ethnographic perspective and the Brazilian organizational studies, authors that were revisited in the theoretical review of this study. The following topics are presented in the following table:

Table 2: Topics of Analysis: Entography, Organizational Studies and Tourism

\begin{tabular}{|c|l|}
\hline Themes of Analysis & Authors \\
\hline $\begin{array}{c}\text { Sociological basis of our } \\
\text { Organizational Studies }\end{array}$ & Cavedon (1999; 2003); Jaime Jr (1996) Serva and Jaime Jr (1995) \\
\hline $\begin{array}{c}\text { Understanding of field two } \\
\text { Estudos Organized }\end{array}$ & $\begin{array}{l}\text { Cavedon (1999; 2003); Andion and Serva (2006); Serva y Jaime Jr (1995) } \\
\text {; JaimeJr (2003); Alcadipani (2009); Yen-Tsang, Dultra-De- } \\
\text { Lima and Pretto (2013); }\end{array}$ \\
\hline $\begin{array}{c}\text { Objectives for application of } \\
\text { ethnographic perpsectiva nos } \\
\text { Estudos Organizacionais }\end{array}$ & $\begin{array}{l}\text { Cavedon (2003); Alcadipani (2009, 2010); Andion } \\
\text { Serva (2006); Jaime Jr. (2003, 2010) }\end{array}$ \\
\hline $\begin{array}{c}\text { Conduct conduction time } \\
\text { Planning, preparation, } \\
\text { conduction and elaboration of } \\
\text { research text }\end{array}$ & $\begin{array}{l}\text { Andion and Serva (2006); Cavedon (1999, 2003); Jaime Jr. (1996; 2003, } \\
\text { 2010);Alcadipani (2010) }\end{array}$ \\
\hline $\begin{array}{c}\text { Culture and tourism, tourism } \\
\text { planning, public policy, the }\end{array}$ & $\begin{array}{l}\text { Samatas (2003); Bowie and Chang (2005); Novelli, Schmitz and Spencer } \\
\text { (2006); Larsen, Urry and Axhausen (2007); Santos (2008); }\end{array}$ \\
\hline
\end{tabular}


ISSN: 2236-269X

DOI: 10.14807/ijmp.v11i7.1230

\begin{tabular}{|c|c|}
\hline market and local communities & $\begin{array}{l}\text { Frohlick and Harrison (2008); Donaire, Silva, and Gaspar (2009); } \\
\text { Yázigi (2009); Christou and } \\
\text { Saveriades (2010); Watson (2011); Rantala (2011); Bianchi and Step } \\
\text { henson (2013); Butnaru (2015); Konu (2015); Bispo (2016); } \\
\text { Magalhães, and Dos-Santos (2016); Sainaghi, Phillips } \\
\text { and Zavarrone (2017); }\end{array}$ \\
\hline $\begin{array}{l}\text { Sociological basis of our } \\
\text { Organizational Studies }\end{array}$ & Cavedon (1999; 2003); Jaime Jr (1996) Serva and Jaime Jr (1995) \\
\hline $\begin{array}{l}\text { Understanding of field two } \\
\text { Estudos Organized }\end{array}$ & $\begin{array}{l}\text { Cavedon (1999; 2003); Andion and Serva (2006); Serva y Jaime Jr (1995) } \\
\text {; JaimeJr (2003); Alcadipani (2009); Yen-Tsang, Dultra-De- } \\
\text { Lima and Pretto (2013); }\end{array}$ \\
\hline $\begin{array}{l}\text { Objectives for application of } \\
\text { ethnographic perpsectiva nos } \\
\text { Estudos Organizacionais }\end{array}$ & $\begin{array}{l}\text { Cavedon (2003); Alcadipani (2009, 2010); Andion } \quad \text { and } \\
\quad \text { Serva (2006); Jaime Jr. }(2003,2010)\end{array}$ \\
\hline Conduct conduction time & $\begin{array}{l}\text { Cavedon (1999, 2003); Serva y Jaime Jr. (1995) Andion y Serva (2006) C } \\
\text { avedon } \\
\text { and Faschin (2003) }\end{array}$ \\
\hline $\begin{array}{l}\text { Planning, preparation, } \\
\text { conduction and elaboration of } \\
\text { research text }\end{array}$ & $\begin{array}{l}\text { Andion and Serva (2006); Cavedon (1999, 2003); Jaime Jr. (1996; 2003, } \\
\text { 2010); } \\
\text { Alcadipani (2010) }\end{array}$ \\
\hline $\begin{array}{l}\text { Culture and tourism, tourism } \\
\text { planning, public policy, the } \\
\text { market and local communities }\end{array}$ & $\begin{array}{l}\text { Samatas (2003); Bowie and Chang (2005); Novelli, Schmitz and Spencer } \\
\text { (2006); Larsen, Urry and Axhausen (2007); Santos (2008); } \\
\text { Frohlick and Harrison (2008); Donaire, Silva, and Gaspar (2009); } \\
\text { Yázigi (2009); Christou and Saveriades (2010); Watson (2011); } \\
\text { Rantala (2011); Bianchi and Stephenson(2013); Butnaru (2015); } \\
\text { Konu (2015); Bispo (2016); Magalhães, and Dos- } \\
\text { Santos (2016); Sainaghi, Phillips and Zavarrone (2017); }\end{array}$ \\
\hline
\end{tabular}

Source: Adapted from Magallanes and Santos (2016), Costa and Fonseca (2018)

The topics of analysis listed (Table 2) were delineated from the review of the literature of the main authors that sought to approximate the ethnographic perspective of organizational studies and tourism in Brazil in recent decades. Thus, from the complete reading of the selected articles, the listing of each article was made and discussed among the authors and, thus, a qualitative analysis was made, based on a critical and reflexive positioning based on the categories shown a priori. From the analysis made it is possible to record the results of this study.

\section{RESULTS OF THE STUDIES}

The results of this study are presented below. Thus, first the analysis of some aspects will be presented, such as university of origin and temporary space, in which the articles were developed. Then, a qualitative analysis based on the categories of analysis defined from the review of the main authors which sought to approximate the ethnographic perspective, organizational studies and tourism in the national sphere and international contributions. 
DOI: 10.14807/ijmp.v11i7.1230

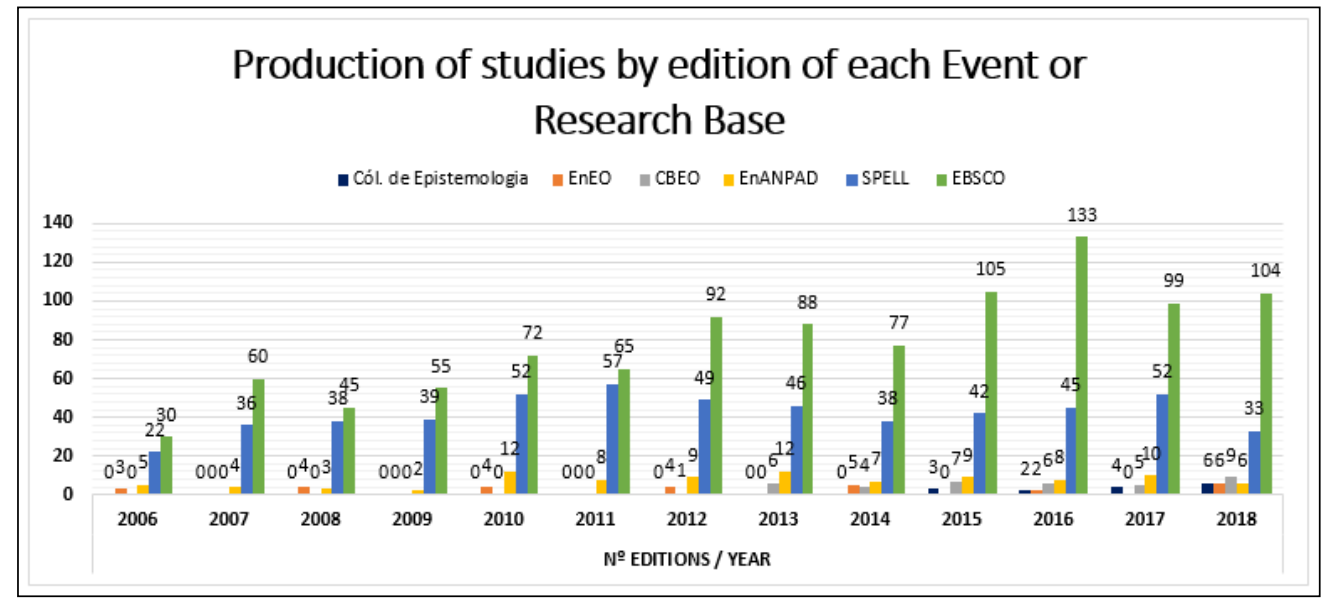

Figure 1: Production of studies by edition of each event / research base Source: Adapted by the authors.

As can be seen in the graphs that make up Figure 1, the events of the National Association of Postgraduate and Management Research (ANPAD), EnANPAD and EnEO, are the events that have the most articles published, mainly due to having more editions made, as well as for standing out as the main events in the area of Brazilian organizational studies. The Colloquium of Epistemology and Sociology of the Science of Administration and the CBEO are more recent events that arise from a divergence of the organizational studies in relation to the mainstream of the studies of the administration.

Consequently, with the emergence of these events, the number of studies that used the ethnographic approach in organizational studies increased, which contributes to the discussion on the possibilities of this approach in the field of organizations. As it is also noticeable from the analysis of the graphics there is no linearity as the publication during the course of the editions, but there is a higher incidence of studies between the years 2010 and 2015 in the events of EnANPAD and EnEO, as well as with the insertion of the Colloquium and the CBEO in the same period of time.

\subsection{Critical and reflexive reflection of the analysis of the studies}

Outlining these first considerations, the critical and reflexive analysis is presented from the previously proposed categories in the methodological aspects. The first category established was "Sociological Base in Organizational Studies", which was pointed out by Cavedon (1999); Jaime Jr. (1996), Serva and Jaime Jr. (1995). According to Cavedon (1999) the ethnography,

The first step for the approximation of the two sciences, which are, Anthropology and Administration, requires a resumption of their theoretical assumptions, from then on to verify the implications that such referential have on the practical performance of those seeking the disengagement of Organizational culture in light of ethnography. 
DOI: 10.14807/ijmp.v11i7.1230

By way of conclusion, a flexibilization in both sciences is proposed as long as the fundamental principles of the sciences are maintained so that both can benefit from interdisciplinary interchangeable exchange (CAVEDON, 1999, p. 1).

Therefore, it is interesting to note that the understanding that organizations are spaces of intensive symbolism (CARRIERI; SARAIVA, 2007) enabled the construction of an important dialogue of Organizational Studies with Anthropology, especially through the development of ethnographies that Budgets are based (YEN-TSANG; DULTRA-DE-LIMA; PRETTO, 2013). In this sense, it is possible to observe that interpretative approaches reproduce the initial understanding of the anthropology of separation between nature and culture, looking for the human capacity to produce symbolic representations (culture) about reality (nature) the understanding of that reality "(FIGUEIREDO; OLIVEIRA, 2015, p. 9).

In the practical studies, in which the ethnographic method was applied, which are the great majority of the studies found, almost the whole highlight the anthropological origin of the ethnographic perspective, as well as the concern for the specificities of the method.

In addition, the researcher's epistemological position in ethnography is important. Based on the results of this study, researchers have a passive role in conducting ethnographic studies and are limited to analyzing the material. In this regard, Tavakoli and Wijesinghe (2014) believe that a deep understanding of online communities can only occur through prolonged engagement and immersion in a culture for an extended period of time. Firstly, it expands our knowledge of using information technology in tourism to conduct online studies in a general sense. Secondly, it increases our understanding of specific new methods for conducting netnographic studies.

The second category consists of the "Understanding of the field of organizational studies", highlighted by Cavedon (1999), Cavedon (2003); Alcadipani (2009); Andion and Serva (2006); Serva and Jaime Jr. (1995); Jaime Jr. (2003). An important consideration to stand out initially is that, as Bispo and Santos (2014) highlights in the area of administration, in the Brazilian sphere, the word organization assumed in the business context and, often, in the academic environment a synonym meaning to the company. This situation makes many people, academics or not, use the word organization with this meaning of company suggesting that such a position is final. However, this issue awakens uncomfortable in a group of researchers who are intensely inclined to the studies of organizations in a broader and more complex way. 
DOI: 10.14807/ijmp.v11i7.1230

The third category proposed was "Objectives for the application of the ethnographic perspective in Organizational Studies", according to Cavedon (2003); Alcadipani (2009), Alcadipani (2010); Andion and Serva (2006) and Jaime Jr. (2003). Broadly, according to Figueiredo and Oliveira (2015), interpretative ethnographies made possible the understanding of the relationship between culture and space in the Administration area, especially via studies on organizational culture. Jaime Jr. (2003), for example, in an ethnographic study on a binational enterprise highlights how symbolic representations and the production of meanings about work constitute different organizational spaces in the same organization. In this perspective, the studies of Cavedon (1988), Cavedon (2014) are pointed out in which the organizational culture ceases to be considered as a manageable phenomenon, considering it as plural, heterogeneous and symbolic. Cavedon (2004, p. 33-34) provides:

"[...] the network of meanings that circulate inside and outside the organizational space, being simultaneously ambiguous, contradictory, complementary, disparate and analogous, involving resemantizations that reveal the homogeneity and organizational heterogeneity".

Another issue that stood out in terms of the application of the ethnographic method was the issue of organizational networks. Andion and Serva (2006) argue that in organizational studies, networks have been the object of many studies, taking into account that in several cases a sense of innovation is attributed to the organizational networks be it in the sphere of civil society, the market or the State.

The fourth category of analysis was delineated from the considerations of Cavedon (1999) Cavedon (2003), Serva and Jaime Jr. (1995), Andion and Serva (2006) and Cavedon and Faschin (2003), and consists of the question of time of conducting ethnographic research. Regarding the conduction of the researches carried out, of the 122 studies, 81 of them had between two and six months of studies in the organizations, other 29 studies had between six months and two years of study and 5 articles had more of 2 years of research.

Thus, as it is possible to perceive, ethnographic studies require time to understand and enable the researcher in the analyzed context, to conquer an interaction with the partner actors that allows understanding the relationships and complexities of social phenomena. Interaction and going to the field is essential, that is, one cannot be a cabinet ethnographer, an expression used by anthropologists to characterize disqualifying ethnographers who do not experience the social fact.

The fifth category "Planning, preparation, conduct and elaboration of the research text" was delineated from Andion and Serva (2006), Cavedon (1999) Cavedon (2003), Jaime Jr. 
DOI: 10.14807/ijmp.v11i7.1230

(1996), Jaime Jr. (2003) and Alcadipani (2010). In the studies there are some precautions in conducting the research. The first one is the preparation of researchers to go to the field, and in that sense, Andion and Serva (2006) argue that one of the basic conditions for the conduct of ethnography is a solid theoretical preparation in the area of knowledge, however, the conception of the field the subject of study goes further.

The sixth category "Culture and tourism, tourism planning, public policies, the market and local communities" focuses on the studies of Cruz (2000), Yázigi (2009), Marcelino (2007) and Beni (2008). The studies torment the integrated planning of tourism to different economic and social activities, also pointing out the importance of national, regional and local sectoral plans to be connected for an adequate development of the territory. As a result, the need for tourism education for public bodies, local businessmen and resident population is observed, as well as the need for a participatory process of the community in the preparation of guidelines for the improvement of tourism. In this way, local development from this activity can achieve, in addition to its economic purpose, such as the involvement of local businesses, social benefits for the communities involved, which will have preserved their cultural manifestations, history and local ecological environment.

A final moment in the conduct of the research is the elaboration of the text, but despite the limitation of the spaces of the articles, the studies in their entirety sought to bring the results of the research in the organizations studied, mainly highlighting the peculiarities of phenomena and the actors studied, as well as their relationships. "This moment of elaboration of the text is considered fundamental in ethnographic research, since according to Laplantine (1996, p. 27)" the ethnographer is expected not only to see and understand what he sees, but also to see ", it is from the text that the researcher can transmit.

Bonetti and Fleischer (2007) point out that one of the richest dimensions of ethnographic work lies in its experimental and artisanal nature. In this way, it becomes impossible to "manualize" ethnography, since each experience will be different, although on the same object of investigation. Therefore, regardless of the type of field experience, the researcher should keep in mind that their interaction and subsequent story about given reality are impregnated by a work ethic, in the sense of respecting the field and its participants.

Thus, it is worth highlighting that it is not a compatible method with functionalist or positivist research questions about a certain phenomenon - whether it is organizational or not. However, it is a method that helps in the raising of theoretical and empirical questions and 
DOI: 10.14807/ijmp.v11i7.1230

propositions of a comprehensive and interpretative background of the lived reality. To these aspects, the researcher must be attentive when planning his "way of approaching" the phenomenon in pattern (DALLA CHIESA; FANTINEL, 2014).

The results of the current research reveal that the majority of researchers did not report prolonged involvement, as researchers must be part of the community for some time, possibly getting involved with other members of the community. In addition, very few researchers have provided a reflective account. Reflexivity helps the reader to understand the researcher's position in the study as they experience the same context. The reflective report can be presented as autonetnography. This type of etnographic study has rarely been published in the tourism discipline (MKONO; RUHANEN; MARKWELL, 2015).

\section{FINAL CONSIDERATIONS}

When analyzing the studies on performance evaluation in an ethnographic approach, it is perceived that there is a wide possibility of development in this field of study, because the current scenario in which the tourism companies are inserted is considered an increasingly turbulent and unstable environment with respect to the political, sociocultural, economic sector and mainly in the development of management strategies, where decision makers constantly seek methods to achieve improvements in organizational performance, because in competitive environments, making decisions and monitoring strategic goals becomes essential in the management process.

In the vision of Magallanes and Santos (2016) the process of conducting ethnographic research is highlighted with the preparation of the researcher and the interaction with the field and social actors that impacts on the preparation of the final text based on theories aligned to the studies organizational

The growth of national and international tourism has led in recent decades to an evolution of the planning and public policies of the sector. Many Brazilian municipalities seek to develop tourist activity in their territory in order to obtain economic gains. However, as important as the financial benefits, is the ability of the segment to promote local development, based on the appreciation of culture, the preservation of the ecological environment and promoting the return to the community.

In this way, for the activity to reach those desirable levels, it is essential to plan for the orderly development of the sector and efficient management of actions to promote and maintain the activity. This process must be carried out horizontally in the different national, state and 
DOI: 10.14807/ijmp.v11i7.1230

local sectoral policies. A social, transport, education and environmental policy must always be associated with tourism policy, once that sector appropriates the spaces for its development.

Business environments strongly marked by competition and uncertainty, where competitive advantages tend to be quickly reproduced and even overcome by competitors, which requires that firms be more active and have an innovative stance, adopt more sophisticated management models, Existing knowledge, have structures that are increasingly effective and at the same time flexible in their decision-making processes (ELBANNA; RODRIGUES, 2010; BRITO; BRITO, 2014).

Flores-Pereira and Cavedón (2009) consider that ethnographic research enables the understanding of culture and organizational space, on the other hand, organizational performance for tourism in the vision of Sainaghi and Baggio (2017) is still not fully articulated, being valid to highlight that there is a continuous expansion of the markets and that has forced Brazilian hotels to become more competitive, due to the increase in the number of international hotel networks operating in the country and the prospect of new entrants, this has led Brazilian hotel networks to improve their management tools (SILVA, 2007; SAINAGHI, PHILLIPS; CORTI, 2013; ALVES, 2013; NUNES, 2016).

The crucial point of this study is to understand the feasibility of developing a multidimensional performance evaluation model for organizational control in companies of the hotel segment through ethnographic research. A subject that has been well researched in recent years, making necessary the theoretical and practical deepening of the study to contribute to the improvement of hotel organizations, which seek information in support of their decisionmaking process, and through the approach discussed and aligned with the Ethnographic surveys with organizational studies can help to see the complexity and diversity of that area.

\section{REFERENCES}

ACERENZA, M. A. (1995) Promoção turística: um enfoque metodológico. São Paulo: Pioneira.

ANDION, C.; SERVA, M. (2006) A Etnografia e os Estudos organizacionais. In: GODOI, C. K.; BANDEIRA-DE-MELO, R.; SILVA, A. B. (2006) Pesquisa Qualitativa em Estudos Organizacionais: Paradigmas, Estratégias e Métodos. São Paulo: Saraiva.

ALCADIPANI, R. (2010) Violência e masculinidade nas relações de trabalho: imagens do campo em pesquisa etnográfica. Cadernos EBAPE.BR, v. 8, n. 1, p. 23-35.

ATKINSON, P.; HAMMERSLEY, M. (1994) Ethnography and Participant Observation. IN: DENZIN, N.; LINCOLN, Y. Handbook of Qualitative Research. Thousand Oaks: Sage. 
DOI: 10.14807/ijmp.v11i7.1230

ALVES, S. (2013) Modelo de mensuração da competitividade turística sustentável de municípios no Brasil. Dissertação (mestrado) - Universidade Federal do Rio de Janeiro, Instituto COPPEAD de Administração, Rio de Janeiro, Brazil.

ARENDIT, E. J. (2002) Introdução à economia do turismo. Campinas-SP: Alinea.

AUGÉ, M. (1999) Voyage et ethnographie. La vie comme recit. L’Homme. v. 39, n. 151.

BARTL, M.; KANNAN, V. K.; STOCKINGER, H. (2016) A review and analysis of literature on netnography research. International Journal of Technology Marketing, v. 11, n. 2, p. 165-196.

BASZANGER, I.; DODIER, N. (1997) Ethnography: relating the part to the whole. In: SILVERMAN, D. Qualitative Research: Theory, Method and Practice. London: Sage, c. 2, p. 9-34,

BELZ, F.-M.; BAUMBACH, W. (2010) Netnography as a method of lead user identification. Creativity and Innovation Management, v. 19, n. 3, p. 304-313.

BENI, M. (2008) Análise estrutural do turismo. São Paulo: SENAC.

BIANCHI, R. (2006) Tourism and the globalization of fear: Analyzing the politics of risk and (in) security in global travel. Tourism and Hospitality Research, v. 7, n. 1, p. 64-74.

BIANCHI, R. V.; STEPHENSON, M. L. (2013) Deciphering tourism and citizenship in a globalized world. Tourism Management, v. 39, n. 1, p. 10-20.

BIGNAMI, R. (2002) A imagem do Brasil no turismo: construções, desafios e vantagens competitivas. São Paulo: Aleph.

BISPO, M. S.; SANTOS, I. S. (2014) A organização do cotidiano na orla de João Pessoa: um olhar etnometodológico da prática do voluntariado. Farol. Revista de Estudos Organizacionais e Sociedade, v. 1, n. 2, p. 379-416.

BISPO, M. S. (2016) Tourism as practice. Annals of Tourism Research. v. 61, p. 170-179.

BLASCO, E. F. (2001) Análisis econômico y turismo. Estúdios y Perspectiva, v. 15, p.5363.

BOWIE, D.; CHANG, J. (2005) Tourist Satisfaction: A view from a mixed international guided package tour. Journal of Vacation Marketing, v. 11, n. 4, p. 302- 322.

BOVET, D. (2001) Redes de valor. São Paulo: Negócio.

BARRETTO, M. (2006) Introdução. In: BANDUCCI-JR, Á.; BARRETTO, M. Turismo e identidade local: uma visão antropológica. Campinas: Papirus, p. 07-20.

BREWER, J. D. (2004) Ethnography. In: CASSELL, C.; SIMON, G. Essential Guide to Qualitative Methods in Organizational Research. Londres: Sage, c. 25, p. 312-322.

BUTNARU, G. I. (2015) The Method of Ethnographic and Content Analysis in Determining Development Factors of Economic and Managerial Tourism Performance. Procedia Economics and Finance, v. 20, p. 104-111.

CAMERON, K. S.; WHETTEN, D. A. (1983) Organizational effectiveness: a comparison of multiple models. San Diego: Academic Press.

CAVEDON, N. R. (2014) A qualidade de vida no trabalho na área da Segurança Pública: uma perspectiva diacrônica das percepções olfativas e suas implicações na saúde dos servidores. Organizações \& Sociedade, v. 21, n. 68, p. 875-892. 
CHEN, K. Y. (2014) Improving importance-performance analysis: The role of the some of tolerance and competitor performance. The case of Taiwan's hot spring hotels. Tourism Management, v. 40, p. 260-272.

CHILD, J.; ELBANNA, S.; RODRIGUES, S. B. (2010) The political aspects of strategic decision- making. In: PAUL, C. N.; WILSON, D. C. The Handbook of Decision Making. Chichester: Wiley.

COSTA, F. L.; CUNHA, A. P. G. (2002) Pensar o desenvolvimento a partir do local: novo desafios para os gestores públicos. Lisboa. In: Anais eletrônicos CLAD... Lisboa: CLAD.

CHRISTOU, P.; SAVERIADES, A. (2010) The use of Ethnography to Explore Tourist Satisfaction Antecedents. An International Multidisciplinary. Journal of Tourism, v. 5, n. 1, p. 89-100.

DALLA CHIESA, C.; FANTINEL, L. (2014) "Quando eu vi, eu tinha feito uma etnografia": notas sobre como não fazer uma "etnografia acidental”. In: Encontro de Estudos Organizacionais da ANPAD, 8, 2014, Gramado. Anais... Rio de Janeiro: Anpad.

DONAIRE, D.; SILVA, M. P.; GASPAR, M. A. (2009) A rede de negócios do turismo: um estudo sobre suas características e implicações estratégicas. Turismo: Visão e Ação, v. 11, n. 1, art. 7, p. 112-134.

FERREIRA, A. J. A. (2007) O Turismo e a produção do espaço no estado do Maranhão, Brasil. Revista Electrónica de Geografía y Ciencias Sociales. v. XI, n. 245, p. 58-7.

FETTERMAN, D. M. (2010) Ethnography step by step. Thousand Oaks: Sage.

FLORES-PEREIRA, M. T.; CAVEDON, N. R. (2009) Os bastidores de um estudo etnográfico: trilhando os caminhos teórico-empíricos para desvendar as culturas organizacionais de uma livraria de shopping center. Cadernos EBAPE.BR, v. 7, n. 1, p. 144160.

FROHLICK, S.; HARRISON, J. (2008) Engaging ethnography in tourist research: An introduction. Tourist Studies, v. 8, n. 1, p. 5-18.

EMBREE, L. (2001) The continuation of Phenomenology: a fifth period? Indo-Pacific. Journal of Phenomenology, v. 1, n. 1.

GRABURN, N. (2009) Turismo e Antropologia: novas abordagens. Campinas, SP: Papirus.

GEERTZ, C. (1978) Por uma Teoria Interpretativa da cultura. In: A interpretação das culturas. Rio de Janeiro: Zahar Editores.

GODELDNER, C. R.; RITCHIE, J. R.; BRENT, M.; ROBERT, W. (2002) Turismo: princípios, práticas e filosofias. São Paulo: Bookman.

GODOI, C. K.; BANDEIRA-DE-MELO, R.; SILVA, A. B. (2006) Pesquisa Qualitativa em Estudos Organizacionais: Paradigmas, Estratégias e Métodos. São Paulo: Saraiva.

GODOY, A. (1995) Pesquisa Qualitativa - tipos fundamentais. Revista de Administração de Empresas, v. 35, n. 3, p. 20-29.

HAMMERSLEY, M.; ATKINSON, P. (1994) Etnografía: métodos de investigación. Barcelona, Paidós.

JAIME-JÚNIOR, P. (2003) Pesquisa em organizações: por uma abordagem etnográfica. Civitas, v. 3, n. 2, p. 435-456. 
DOI: 10.14807/ijmp.v11i7.1230

JUPP, V. (2006) The Sage Dictionary of Social Research Methods. Londres: Sage, KAPLAN, R. S.; NORTON, D. P. (1992) The Balanced Scorecard: Measures that drive Performance. Harvard Business Review. January-February. p. 10-80.

KONU, H. (2015) Developing a forest-based wellbeing tourism product together with customers - An ethnographic approach. Tourism Management. v. 49, p. 1-16.

KOZINETS, R. V. (2012) 'Marketing netnography: prom/ot(ulgat)ing a new research method'. Methodological Innovations Online, v. 7, n. 1, p. 37-45.

LARSEN, J.; URRY, J.; AXHAUSEN, K. W. (2007) Networks and tourism: mobile social life. Annals of Tourism Research, v. 34, n. 1, p. 244-262.

LEAL, R. E. S. (2010) A etnografia no estudo turismo sob a perspectiva antropológica. In: Anais da Associação Brasileira de Pesquisa e Pós-Graduação em Turismo, São Paulo, SP, Brasil. p. 1-12.

LEWIN, A. Y.; MINTON, J. W. (1986) Determining organizational effectiveness: another look, and agenda for research. Management Science, v. 32, n. 5, p. 514-538.

LUGOSI, P. (2014) Hospitality and organizations: Enchantment, entrenchment and reconfiguration. Hospitality and Society, v. 4, n. 1, p. 75-92.

MAGALHÃES, T. G.; DOS-SANTOS, G. L. (2016) Etnografia e Estudos Organizacionais: Análise da Produção Científica Brasileira. Revista Brasileira de Estudos Organizacionais. v. 3. n. 2, p. 145-170.

MILLER, C. C.; WASHBURN, N. T.; GLICK, W. H. (2013) The myth of firm performance. Organisation Science, v. 24, n. 3, p. p. 948-964.

MKONO, M.; RUHANEN, L.; MARKWELL, K. (2015) From netnography to autonetnography in tourism studies. Annals of Tourism Research, v. 52, p. 167-169.

MORGAN, G.; BERGAMINI, C. W.; CODA, R. (1996) Imagens da organização. São Paulo: Atlas.

NOGUEIRA, M. G. (1987) O papel do turismo no desenvolvimento Econômico e social do Brasil. RAP, v. 21, n. 2, p. 37-54.

NOVELLI, M.; SCHMITZ, B.; SPENCER, T. (2006) Networks, clusters and innovation in tourism: A UK experience. Tourism Management, London, v. 27, n. 6, p. 1141-1152.

NUNES, C. R. (2016) Métodos de avaliação de desempenho dos hotéis: estudo empírico em Portugal. Tese (Doutorado em Gestão Geral, Estratégia e Desenvolvimento Empresarial) - Instituto Universitário de Lisboa - ISCTE - IUL. Escola de Gestão. Lisboa, Portugal.

PALMER, C. (2005) An Ethnography of Englishness: Experiencing identity through tourism. Annals of Tourism Research, v. 32, n. 1, p. 7-27.

PAVLATOS, O.; PAGGIOS, I. (2009) A survey of factors influencing the cost system design in hotels. International Journal of Hospitality Management, v. 28, n. 2, p. 263-271.

PIAGET, J. (1990) Epistemologia Genética. São Paulo: Martins Fontes.

PIOLA, F. G.; ANDRADE, D. C. G.; KUSHANO, E. S. (2018) Etnografia e Turismo: Um Estudo das Percepções e Sentimentos de Crianças Residentes na Ilha Do Mel - PR. Applied Tourism, v. 3, n. 2, p. 01-35.

PINTO, R.; PEREIRO, X. (2010) Turismo e antropologia: contribuições para um debate plural. Turismo e Desenvolvimento, p. 219-226. 
RANTALA, O. (2011) An Ethnographic Approach to Nature-based Tourism. Journal of Hospitality and Tourism Management, v. 11, n. 2, p. 150-165.

ROCHA-PINTO, S. R.; FREITAS, A. S.; MAISONNAVE, P. R. (2010) Métodos interpretativistas em Administração: implicações para pesquisadores. FACES, v. 9, n. 1.

REMENYI, D.; WILLIAMS, B.; MONEY, A.; SWARTZ, E. (1998) Doing research in business and management: an introduction to process and method. Research Methods for Business \& Management, Sage.

RITCHIE, R.; RITCHIE, J. (2002) A framework for an industry supported destination marketing information system. Tourism Management. v. 23, p. 439-454.

SAINAGHI, R. (2010a) Hotel performance: State of the art. International Journal of Contemporary Hospitality Management, v. 22, n. 7, p. 920-952.

SAINAGHI, R.; PHILLIPS, P.; CORTI, V. (2013) Measuring hotel performance: Using a balanced scorecard perspectives' approach. International Journal of Hospitality Management, v. 34, n. 1, p. 150-159.

SAINAGHI, R.; PHILLIPS, P.; ZAVARRONE, E. (2017) Performance measurement in tourism firms: A content analytical meta-approach. Tourism Management, v. 59, p. 36-56.

SAINAGHI, R.; DE CARLO, M. (2016) How to create destination capabilities in the Field of new product development. In: PECHLANER, H.; INNERHOFER, E. (Eds.; p.

Competence-based innovation in hospitality and tourism, Routledge, p. 185-196.

SAINAGHI, R.; BAGGIO, R. (2017) Complexity traits and dynamics of tourism destinations. Tourism Management, v. 63, p. 368-382.

SAMATAS, M. (2003) Greece in 'Schengenland': blessing or anathema for citizens and foreigners’ rights. Journal of Ethnic and Migration Studies, v. 29, n. 1, p. 141-156.

SANTANA, A. (2009) Antropologia do turismo: analogias, encontros e relações. São Paulo: Aleph.

SILVA, D. E. P. (2007) Sistema de mensuração de desempenho: proposta de um modelo para a indústria de Hospitalidade. Tese (Doutorado) - Universidade Federal de Pernambuco. Programa de Pós-Graduação em Engenharia de Produção, Pernambuco, Brasil,

SMITH, V. L. (1998) War and tourism: An American ethnography. Annals of Tourism Research, v. 25, n. 1, p. 202-227.

SPOHR, N.; CAVALCANT, M. F. R. (2013) Etnografia e Estudos Organizacionais Críticos no Brasil. In: XXXVII Anais do Encontro da ANPAD, Set.; Rio de Janeiro, p. 1-13.

TAVAKOLI, R.; WIJESINGH, S. N. R. (2019) The evolution of the web and ethnography in tourism: A systematic review. Tourism Management Perspectives. v. 29, p. 48- 55.

TEDLOCK, B. (2000) Ethnography and Ethnography Representation. In: DENZIN, N. K.; LINCOLN, Y. Handbook of Qualitative Research. Thousand Oakds, CA: Sage.

TOMELIN, C. A. (2001) Mercado de agências de viagens e turismo: como competir diante das novas tecnologias. São Paulo: Aleph.

UNWTO. World Tourism Organization. (2012) Compendium of Tourism Statistics. Database, UNWTO, Madrid.

UNWTO. World Tourism Organization. (2013) Tourism Highlights. Database UNWTO, Madrid. 
DOI: 10.14807/ijmp.v11i7.1230

VERGARA, S. C. (2008) Métodos de pesquisa em administração. São Paulo: Atlas.

WATSON, T. J. (2011) Ethnography, reality, and truth: The vital need for studies of 'how things work' in organizations and management. Journal of Management Studies, v. 48, n. 1, p. 202-217.

YEN-TSANG, C.; DULTRA-DE-LIMA, R. G.; PRETTO, K. (2013) Análise qualitativa das publicações nacionais e internacionais em etnografias em administração e estudos organizacionais. RAEP, v. 14, n. 2, p. 21-247.

YÁZIGI, E. (2009) Saudades do futuro: por uma teoria do planejamento territorial do turismo. São Paulo: Plêiade. 